\title{
EFEK DIVERSIFIKASI PEMBIAYAAN SEKTOR EKONOMI TERHADAP PROFITABILITAS DAN RISIKO BANK SYARIAH DI INDONESIA
}

\author{
Muhammad Khozin Ahyar \\ Institut Agama Islam Negeri (IAIN) Surakarta, Sukoharjo, Indonesia \\ khozinahyar@gmail.com \\ https://doi.org/10.46367/jps.v2i2.388
}

Received: Aug 23, 2021 Revised: Sep 12, 2021 Accepted: Sep 28, 2021 Published: Oct 14, 2021

\begin{abstract}
Financing in Islamic banking can be regarded as an investment because Islamic banking is a fund manager (mudharib) from the owner of the funds (shahibul maal), namely the customer. This research aims to show that investment diversification can minimize risk and increase profitability in Islamic banking. This study uses a quantitative method with a multiple linear regression model with 14 independent and 2 dependent variables. The data used is secondary data obtained from the Islamic banking statistics of the Financial Services Authority. The result of this research is that diversification of financing based on the economic sector has no effect on profitability but affects risk in reducing default. This research has implications for reducing the risk of default in Islamic banking, marked by the performance and quality of Islamic banking financing getting better.
\end{abstract}

Keywords: Diversification, Financing, Profitability, Risk.

\begin{abstract}
ABSTRAK
Pembiayaan dalam perbankan syariah dapat dikatakan sebagai suatu investasi, karena perbankan syariah merupakan pengelola dana (mudharib) dari pemilik dana (shahibul maal) yaitu nasabah. Penelitian ini bertujuan untuk memperlihatkan diversifikasi investasi dapat yang berefek dalam meminimalisir risiko serta meningkatkan profitabilitas pada perbankan syariah. Penelitian ini menggunakan metode kuantitatif dengan model regresi linear berganda dengan 14 variabel independen dan 2 variabel dependen. Data yang digunakan adalah data sekunder yang diperoleh dari statistik perbankan syariah Otoritas Jasa Keuangan. Hasil dari penelitian ini adalah bahwa diversifikasi pembiayaan berdasarkan sektor ekonomi tidak memiliki pengaruh terhadap profitabilitas, namun berpengaruh terhadap risiko dalam menekan gagal bayar. Penelitian ini berimplikasi pada penurunan risiko gagal bayar pada perbankan syariah yang ditandai dengan kinerja dan kualitas pembiayaan perbankan syariah semakin membaik.
\end{abstract}

Kata Kunci: Diversifikasi, Pembiayaan, Profitabilitas, Risiko. 


\section{PENDAHULUAN}

Bank syariah merupakan lembaga keungan yang mengintermediasi antara pemilik dana atau pihak yang berkelebihan dana (surplus) dan juga pihak yang kekurangan dana (deficit) (Puspitasari 2018). Kegiatan atau aktifitas bank syariah adalah menghimpun dana dari masyarakat serta menyalurkan dana kepada masyarakat (Presiden RI 2008). Selain itu, bank syariah juga dapat memberikan jasa sebagai lalu lintas pembayaran dalam kegiatannya. Dalam rangka menghimpun dana dari masyarakat, bank syariah menggunakan produk simpanan seperti tabungan, giro dan deposito sebagai instrumen atau alat dalam mengumpulkan dana. Sementara, untuk menyalurkannya bank syariah menggunakan berbagai produk pembiayaan, seperti pembiayaan dengan akad murabahah, mudharabah, musyarakah dan lain sebagainya. Sistem penyaluran dana atau pembiayaan inilah yang membuat bank syariah memiliki keunikan tersendiri dibandingkan bank konvensional, karena produk pembiayaan di bank syariah memiliki beragam model dalam menyalurkan pembiayaan.

Keunikan lainnya dari bank syariah adalah perannya yang dapat dikatakan multifungsi. Bank syariah dapat menjadi manajer investasi, investor, penyedia jasa keuangan dan lain sebagainya (Suryanto and Nasrulloh 2016). Fungsinya sebagai manajer investasi dan juga investor menjadikan bank syariah harus memperkuat tingkat kepercayaan dari masyarakat. Salah satu upaya dalam meningkatkan kepercayaan dari masyarakat adalah dengan mengelola dana-dana dari masyarakat secara baik dan benar. Selain itu juga, prinsip kehati-hatian juga harus selalu dihadirkan dalam mengelola dana masyarakat yang jumlahnya sangat besar, terutama ketika menyalurkan dana dalam bentuk pembiayaan. Ketika menyalurkan dana kepada masyarakat ada dua hal yang mungkin bisa terjadi, yaitu risiko dan profit. Risiko yang kemungkinan dihadapai adalah kerugian berupa kredit macet, sedangkan profit yang kemungkinan diperoleh adalah laba dari bagi hasil, margin ataupun ujrah.

Ketika bank syariah berperan sebagai manajer investasi dan juga investor pasti memiliki perencanaan dalam meminimalisir risiko, salah satu caranya adalah dengan mendiversifikasi pembiayaan. Ketika bank syariah menyalurkan pembiayaan, maka bank syariah sedang melakukan perannya sebagai manajer investasi dan juga investor yang menginvestasikan dana dari masyarakat. Diversifikasi dapat diartikan sebagai pembagian dana ke dalam beberapa tempat atau instrumen. Teori portofolio investasi yang dikemukakan oleh Markowitz (1952) yaitu "don't put all your eggs in one basket" sangat tepat digunakan untuk perusahaan yang akan melakukan peran sebagai manajer investasi dan juga investor, dalam hal ini bank syariah (Masruroh 2018a). Tujuan dari diversifikasi sendiri adalah untuk mengurangi atau meminimalisir risiko dari total portofolio yang dimiliki. Menurut Masruroh (2018a), dilakukannya portofolio atau diversifikasi ketika melakukan investasi atau pembiayaan, sehingga dapat mengurangi terjadinya risiko kegagalan pembiayaan dan meningkatkan profitabilitas.

Christianti (2011) menyatakan bahwa diversifikasi pembiayaan atau kredit pada sektor ekonomi memiliki pengaruh terhadap profitabilitas perbankan, sedangkan penelitian yang dilakukan oleh Masruroh (2018b); Suryanto and Nasrulloh (2016) menyatakan bahwa diversifikasi pembiayaan pada sektor 
ekonomi tidak memiliki pengaruh terhadap profitabilitas bank syariah. Disamping itu, salah satu tujuan dari diversifikasi adalah untuk mengelola atau meminimalisir risiko. Wahyudi et al. (2013) menyatakan bahwa strategi diversifikasi dapat meminimalisir terjadinya kerugian. Teori tersebut berbanding terbalik dengan hasil penelitian yang dilakukan oleh Masruroh (2018a) yang menyatakan bahwa secara parsial diversifikasi pembiayaan tidak berpengaruh terhadap non performing financing $(N P F)$. NPF dalam perbankan merupakan salah satu risiko kerugian (gagal bayar) yang harus dihadapi oleh perbankan syariah. Namun dengan adanya pertentangan tersebut maka perlu dilakukan penelitian lanjutan mengenai hal tersebut dengan metode dan data yang berbeda. Oleh sebab itu penelitian ini bertujuan untuk memperlihatkan diversifikasi investasi dapat yang berefek dalam meminimalisir risiko serta meningkatkan profitabilitas pada perbankan syariah.

\section{TELAAH LITERATUR}

\section{Diversifikasi}

Diversifikasi merupakan pembagian aset ke dalam beberapa instrumen atau sektor dalam rangka memaksimalkan keuntungan serta meminimalisir risiko. Hal tersebut didasarkan pada pernyataan Markowitz (1952) sebagaimana yang dikutip oleh Masruroh (2018b) bahwa "jangan menaruh telur di dalam sebuah keranjang”. Diversifikasi juga dapat diartikan sebagai salah satu strategi dalam mengelola portofolio aset yang dimiliki. Diversifkasi pembiayaan atau kredit yang dilakukan oleh perbankan memang diharapkan dapat mengendalikan risiko yang kemungkinan bisa terjadi kapanpun (Christianti 2011). Bahkan dalam aturan, perbankan dituntut untuk melakukan diversifikasi terhadap kredit atau pembiayaan yang mereka salurkan (OJK 2018). Penelitian yang dilakukan oleh Lis, Pagés, and Saurina (2000) menyatakan bahwa salah satu faktor yang dapat mempengaruhi level kredit bermasalah adalah komposisi portofolio kredit. Komposisi portofolio kredit tersebut akan memainkan peranan penting sebagai indikator profil risiko yang akan dihadapi oleh bank.

\section{Pembiayaan Bank Syariah}

Pembiayaan merupakan salah satu aktifitas atau kegiatan yang dilaksanakan oleh bank syariah dalam menyalurkan dana kepada masyarakat. Ketika bank syariah menyalurkan pembiayaan kepada masyarakat, maka bank syariah berperan sebagai investor dan juga manajer investasi (OJK 2021). Peran bank syariah sebagai investor disebabkan karena bank syariah menyalurkan asetaset yang dimiliki untuk memperoleh keuntungan (Mansur 2011). Sementara dikatakan sebagai manajer investasi karena sebagian dana yang mereka salurkan pada pembiayaan merupakan dana milik nasabah (Anshori 2018).

Pada perbankan syariah terdapat beberapa skema dalam menyalurkan pembiayaan, seperti skema jual-beli, bagi hasil dan sewa (Karim 2014; Puspitasari 2018). Skema jual beli pada bank syariah biasanya dilakukan dengan beberapa akad, seperti murabahah, salam dan istishna. Berdasarkan statistik perbankan syariah Otoritas Jasa Keuangan (OJK) (2020) akad skema jual beli mayoritas yang paling banyak digunakan pada perbankan syariah di Indonesia adalah akad 
murabahah. Sementara, untuk akad dengan skema bagi hasil yang mayoritas digunakan adalah akad musyarakah (OJK 2020).

\section{Profitabilitas}

Profitabilitas merupakan suatu gambaran tentang kemampuan perusahaan (perbankan syariah) dalam menghasilkan laba dan dapat dilihat dalam bentuk rasio seperti return on asset (ROA) (Muhamad 2015). Semakin besar rasio ROA suatu bank, maka akan semakin besar tingkat keuntungan yang dicapai bank dan semakin baik posisi bank dari peningkatan dana pihak ketiga (DPK) yang dihimpun (Mahmudah 2017). Laba atau keuntungan perbankan syariah diperoleh melalui berbagai kegiatan bisnis yang mereka jalankan, seperti penjualan produk berbasis jual-beli (margin), bagi hasil (PLS), sewa-menyewa dan jasa (ujrah/fee) (Muhamad 2015).

Besarnya profit atau tingkat keuntungan yang dihasilkan oleh perbankan syariah bergantung pada faktor internal dan eksternal. Faktor internal merupakan faktor yang penyebabnya berasal dari dalam perusahaan (perbankan syariah), antara lain pengendalian biaya-biaya, segmentasi bisnis dan pengendalian pendapatan. Faktor eksternal merupakan faktor yang penyebabnya berasal dari luar perusahaan (perbankan syariah) atau yang tidak dapat dikendalikan oleh perusahaan, antara lain kondisi ekonomi dan persaingan bisnis di wilayah beroperasinya bank syariah. Pemilihan segmentasi yang tepat dan beragam dapat menjadi pemicu peningkatan profitabilitas perbankan, sebagaimana penelitian yang dilakukan oleh (Christianti 2011).

\section{Risiko}

Perbankan syariah sebagai salah satu lembaga keuangan yang sah di Indonesia memiliki beberapa risiko yang harus dihadapi, seperti risiko likuiditas, risiko kepatuhan, risiko strategis, risiko pasar, risiko hukum dan lain sebagainya (Saufanny and Khomsatun 2019). Namun, ada satu risiko yang merupakan khas dari perbankan syariah yang tidak dimiliki oleh perbankan konvensional, yaitu risiko syariah. Risiko syariah pada lembaga keuangan syariah terutama pada perbankan syariah memiliki dampak yang dapat menyebar ke beberapa risiko lainnya. Sebagai contoh, apabila suatu produk perbankan syariah tidak sesuai dengan syariah, maka juga dapat mempengaruhi risiko yang lainnya, seperti risiko kepatuhan, risiko hukum, risiko strategis dan lain sebagainya.

Salah satu risiko yang menjadi titik fokus pada penelitian ini adalah risiko pembiayaan. Risiko pembiayaan merupakan risiko yang harus dihadapi oleh perbankan syariah sebagai akibat dari kegagalan nasabah dalam membayar angsuran atau kewajibannya. Menurut IFSB (Islamic Financial Service Board), risiko kredit adalah potensi kegagalan debitur atau sekutu bisnis dalam memenuhi kewajiban sesuai perjanjian yang disepakati. Hal ini meliputi seluruh transaksi pembiayaan, seperti jual beli (murabahah, salam, istishna'), utang piutang (qardhul hasan), sewa (ijarah) (Christianti 2011). Tujuan pengelolaan risiko kredit adalah untuk membatasi atau mengurangi risiko kredit, mengklasifikasi aset dan mengevaluasi secara periodik kualitas kolektabilitas portofolio pembiayaan, menetapkan provisi kerugian, dan menyediakan cadangan modal untuk menyerap kerugian yang mungkin terjadi (Wahyudi et al. 2013). Risiko pembiayaan pada 
perbankan syariah dapat digambarkan melalui rasio $N P F$. Rasio $N P F$ merupakan rasio pembiayaan yang bermasalah dalam perbankan syariah.

\section{Pengembangan Hipotesis}

Penelitian yang membahas pengaruh mengenai diversifikasi kredit atau pembiayaan berdasarkan sektor ekonomi terhadap profitabilitas sudah pernah dilakukan oleh Masruroh (2018b); Prastiwi and Anik (2020) yang menyatakan bahwa diversifikasi kredit atau pembiayaan berdasarkan sektor ekonomi berpengaruh terhadap profitabilitas perbankan. Maka dari itu dapat dibentuk hipotesis pertama yaitu: $\mathrm{H}_{1}$ : diversifikasi pembiayaan berdasarkan sektor ekonomi berpengaruh terhadap profitabilitas (ROA).

Penelitian yang membahas pengaruh diversifikasi kredit atau pembiayaan berdasarkan sektor ekonomi terhadap risiko kredit atau pembiayaan sudah pernah dilakukan oleh Christianti (2011); Prastiwi and Anik (2020) yang menyatakan bahwa diversifikasi kredit atau pembiayaan berdasarkan sektor ekonomi berpengaruh dalam mengurangi risiko kredit atau pembiayaan. Maka dari itu dapat dibentuk hipotesis kedua yaitu: $\mathrm{H}_{2}$ : diversifikasi pembiayaan berdasarkan sektor ekonomi berpengaruh terhadap risiko gagal bayar $(N P F)$.

\section{METODE PENELITIAN}

Penelitian ini menggunakan metode kuantitatif dengan model regresi linear berganda. Regresi linear berganda merupakan bagian dari regresi yang menganalisis beberapa variabel independen terhadap satu variabel dependen (Widarjono 2018). Pada penelitian ini data data akan dilakukan regresi sebanyak dua kali, karena peneliti memiliki dua variabel dependen, yaitu $N P F$ dan $R O A$. Sebelum menginterpretasikan hasil estimasi regresi lebih dalam, peneliti melakukan beberapa uji agar data yang digunakan terhindar dari bias, sehingga hasil penelitian dapat dikatakan BLUE (Best, Linear, Unbiased, Estimator).

Beberapa uji yang harus dilalui dalam regesi linear berganda disebut sebagai uji asumsi klasik, yang terdiri dari uji normalitas, uji autokorelasi, heteroskedastisitas dan uji multikolinearitas. Uji normalitas merupakan uji yang bertujuan untuk mengetahui distribusi normal sebuah data yang digunakan dalam penelitian (Nuryanto and Pambuko 2018). Uji autokorelasi merupakan uji yang bertujuan untuk mengetahui korelasi antar variabel gangguan satu observasi dengan anggota observasi lainnya yang berlainan waktu (Widarjono 2018).

Uji multikolinearitas merupakan uji yang bertujuan untuk mengetahui hubungan antar variabel independen dalam suatu model regresi (Nuryanto and Pambuko 2018). Multikolinearitas hanya terjadi pada model regresi linear berganda. Uji asumsi klasik yang lainnya adalah heteroskedastisitas. Heteroskedastisitas muncul apabila residual dari model yang diamati tidak memiliki varians yang konstan dari satu observasi ke observasi lainnya (Nuryanto and Pambuko 2018). Apabila terjadi heteroskedastisitas pada model regresi yang digunakan, maka model Ordinary Least Square (OLS) tetap tidak bias dan konsisten. Masalah heteroskedastisitas sering terjadi pada data yang bersifat cross section dibandingkan dengan data time series.

Data yang digunakan merupakan data sekunder yang diperoleh dari statistik perbankan syariah OJK dari bulan Januari 2015 hingga Desember 2020 
(OJK 2020). Pembiayaan yang disalurkan oleh bank syariah berdasarkan sektor ekonomi dibagi menjadi beberapa subsektor sebagaimana yang terdapat pada Tabel 1. Namun, peneliti hanya mengambil 14 subsektor untuk dijadikan sampel penelitian. Dipilihnya 14 subsektor ini didasarkan pada jumlah outstanding pembiayaan yang paling besar. Selain data pembiayaan berdasarkan sektor ekonomi, peneliti juga menggunakan data ROA Bank Umum Syariah (BUS) dan Unit Usaha Syariah (UUS) sebagai gambaran atas profitabilitas bank syariah serta data $N P F$ sebagai gambaran atas risiko kredit yang dialami oleh bank syariah di Indonesia.

Tabel 1. Variabel Penelitian

\begin{tabular}{cl}
\hline Kode & \multicolumn{1}{c}{ Nama } \\
\hline ROA & Return on Asset (Profitabilitas) \\
NPF & Non Perform Financing (Risiko Gagal Bayar) \\
X1 & Pertanian, Perkebunan \& Kehutanan \\
X2 & Perikanan \\
X3 & Pertambangan \& Penggalian \\
X4 & Industri Pengolahan \\
X5 & Listrik, Gas \& Air \\
X6 & Konstruksi \\
X7 & Perdagangan Besar \& Eceran \\
X8 & Penyediaan Akomodasi \& Penyediaan Makan dan Minum \\
X9 & Transportasi, Pergudangan \& Komunikasi \\
X10 & Perantara Keuangan \\
X11 & Real Estate, Usaha Persewaan \& Jasa Perusahaan \\
X12 & Jasa Pendidikan \\
X13 & Jasa Kesehatan \& Kegiatan Sosial \\
X14 & Jasa Kemasyarakatan, Sosial Budaya, Hiburan \& Perorangan Lainnya \\
\hline
\end{tabular}

\section{HASIL DAN PEMBAHASAN PENELITIAN}

\section{Uji Normalitas}

\section{Gambar 1. Hasil Uji Normalitas}

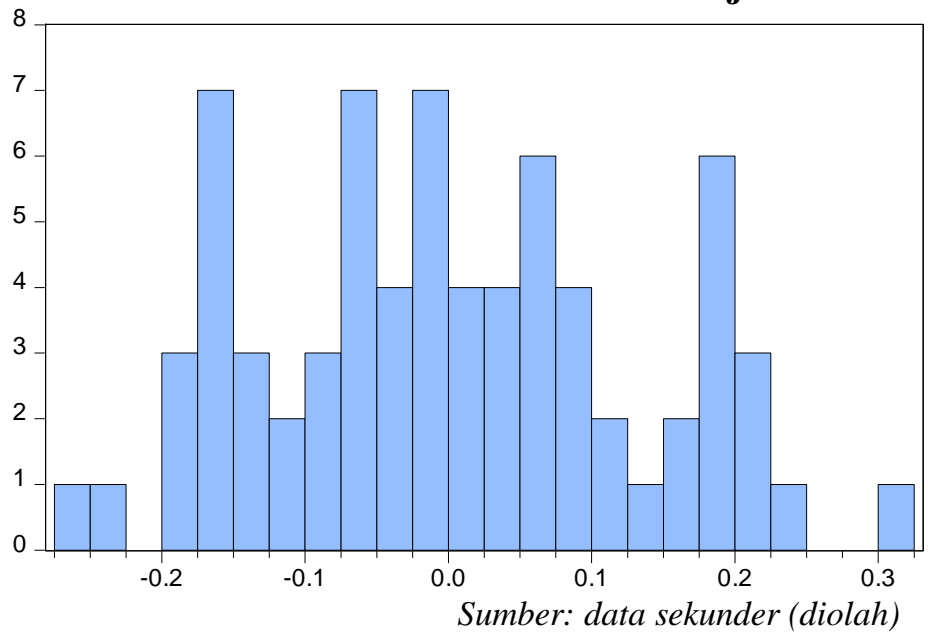

Series: Residuals Sample 2015M01 2020M12 Observations 72

Mean 2.95e-16

Median $\quad-0.017929$

Maximum $\quad 0.311842$

Minimum $\quad-0.274525$

Std. Dev. $\quad 0.130814$

Skewness $\quad 0.190310$

Kurtosis $\quad 2.273941$

Jarque-Bera $\quad 2.016098$

Probability $\quad 0.364930$ 
Uji normalitas akan menguji kenormalan distribusi data yang akan dianalisis dalam penelitian kuantitatif. Kriteria pengujian dapat dilihat dari nilai probabilitas. Aturannya adalah jika nilai probabilitas lebih besar dari nilai alpa $(0,05)$ maka data terdistribusi normal, sebaliknya data tidak terdistribusi secara normal. Berdasarkan Gambar 1, nilai probabilitas sebesar 0,364930 lebih besar dari alpha $(0,364930>0,05)$. Dengan demikian, dapat dikatakan bahwa data yang digunakan dalam penelitian terdistirbusi normal.

\section{Uji Multikolinearitas}

Hasil uji multikolinearitas dapat dilihat pada Tabel 2 menunjukkan bahwa model regresi tidak terdapat multikolinearitas. Hal tersebut dikarenakan bahwa nilai korelasi $<0,8$. Hasil tersebut berdasarkan pada kriteria pengujian, jika nilai korelasi > 0,8 maka terdapat masalah multikolinearitas, jika nilai correlation < 0,8 maka tidak terdapat masalah multikolinearitas (Nuryanto and Pambuko 2018).

Tabel 2. Hasil Uji Multikolinearitas

\begin{tabular}{|c|c|c|c|c|c|c|c|}
\hline & $\mathbf{D}(\mathbf{X} 1)$ & $\mathrm{D}(\mathrm{X} 2)$ & $\mathrm{D}(\mathrm{X3})$ & $\mathrm{D}(\mathrm{X} 4)$ & D(X5) & $\mathrm{D}(\mathrm{X6})$ & $\mathbf{D}(\mathbf{X} 7)$ \\
\hline $\mathbf{D}(\mathbf{X} 1)$ & 1,000000 & 0,101484 & 0,093795 & 0,268738 & $-0,023748$ & 0,002550 & 0,133211 \\
\hline $\mathrm{D}(\mathrm{X} 2)$ & 0,101484 & 1,000000 & 0,248572 & 0,044054 & 0,108037 & $-0,050160$ & $-0,041759$ \\
\hline $\mathrm{D}(\mathrm{X} 3)$ & 0,093795 & 0,248572 & 1,000000 & 0,028345 & $-0,114783$ & $-0,091543$ & $-0,022048$ \\
\hline D(X4) & 0,268738 & 0,044054 & 0,028345 & 1,000000 & 0,113708 & 0,100543 & 0,088026 \\
\hline D(X5) & $-0,023748$ & 0,108037 & $-0,114783$ & 0,113708 & 1,000000 & 0,152214 & $-0,136965$ \\
\hline D(X6) & 0,002550 & $-0,050160$ & $-0,091543$ & 0,100543 & 0,152214 & 1,000000 & 0,110904 \\
\hline $\mathbf{D}(\mathbf{X} 7)$ & 0,13 & $-0,041759$ & $-0,022048$ & 0,088026 & $-0,136965$ & 0,110904 & 1,000000 \\
\hline $\mathrm{D}(\mathrm{X8})$ & 0,15 & 0,146267 & 0,047113 & 0,074940 & $-0,059101$ & $-0,058427$ & 0,009275 \\
\hline D(X9) & 0,118171 & 0,285206 & 0,017607 & 0,210818 & $-0,019862$ & 0,171961 & 0,087886 \\
\hline D(X10) & 0,118010 & $-0,024703$ & 0,219388 & 0,211680 & 0,117650 & 0,199272 & 0,119589 \\
\hline D(X11) & 0,018829 & 0,188406 & 0,028420 & 0,235693 & $-0,010920$ & 2748 & 3533 \\
\hline $\mathrm{D}(\mathrm{X} 12)$ & 0,186366 & 0,274600 & 0,061029 & 0,18 & 0,076083 & 705 & 5864 \\
\hline D(X13) & $-0,004465$ & 0,000344 & $-0,005181$ & 0,057130 & 0,152031 & 7626 & 0,001616 \\
\hline & 0,055799 & $-0,438233$ & 0,095204 & 0,174680 & 0,033697 & 0,145443 & 0,171765 \\
\hline & $\mathrm{D}(\mathrm{X8})$ & D(X9) & $\mathrm{D}(\mathrm{X} 10)$ & $\mathrm{D}(\mathrm{X11})$ & $\mathrm{D}(\mathrm{X} 12)$ & D(X13) & $\mathrm{D}(\mathrm{X} 14)$ \\
\hline D(X1) & 0,158022 & 0,118171 & 0,118010 & 0,018829 & 0,186366 & $-0,004465$ & 0,055799 \\
\hline $\mathrm{D}(\mathrm{X} 2)$ & 0,146267 & 0,285206 & $-0,024703$ & 0,188406 & 0,274600 & 0,000344 & $-0,438233$ \\
\hline $\mathrm{D}(\mathrm{X} 3)$ & 0,047113 & 0,017607 & 0,219388 & 0,028420 & 0,061029 & $-0,005181$ & 0,095204 \\
\hline $\mathbf{D}(\mathrm{X} 4)$ & 0,074940 & 0,210818 & 0,211680 & 0,235693 & 0,187929 & 0,057130 & 0,174680 \\
\hline D(X5) & $-0,059101$ & $-0,019862$ & 0,117650 & $-0,010920$ & 0,076083 & 0,152031 & 0,033697 \\
\hline D(X6) & $-0,058427$ & 0,171961 & 0,199272 & 0,182748 & 0,089705 & 0,147626 & 0,145443 \\
\hline $\mathbf{D}(\mathbf{X} 7)$ & 0,009275 & 0,087886 & 0,119589 & 0,333533 & 0,005864 & 0,001616 & 0,171765 \\
\hline $\mathrm{D}(\mathrm{X8})$ & 1,000000 & 0,016676 & $-0,000803$ & $-0,026673$ & 0,281993 & 0,138559 & 0,057076 \\
\hline D(X9) & 0,016676 & 1,000000 & 0,068931 & 0,288503 & 0,155932 & 0,079346 & 0,075428 \\
\hline $\mathbf{D}(\mathbf{X 1 0})$ & $-0,000803$ & 0,068931 & 1,000000 & 0,314899 & 0,278816 & 0,317809 & 0,317528 \\
\hline D(X11) & $-0,026673$ & 0,288503 & 0,314899 & 1,000000 & 0,190822 & 0,213716 & 0,020188 \\
\hline $\mathrm{D}(\mathrm{X} 12)$ & 0,281993 & 0,155932 & 0,278816 & 0,190822 & 1,000000 & 0,372263 & $-0,005256$ \\
\hline D(X13) & 0,138559 & 0,079346 & 0,317809 & 0,213716 & 0,372263 & 1,000000 & 0,087546 \\
\hline $\mathrm{D}(\mathrm{X} 14)$ & 0,057076 & 0,075428 & 0,317528 & 0,020188 & $-0,005256$ & 0,087546 & 1,000000 \\
\hline
\end{tabular}

Sumber: data sekunder (diolah) 


\section{Uji Heteroskedastisitas}

Uji asumsi $O L S$ yang selanjutnya adalah uji heteroskedastisitas. Uji ini akan mengetahui varian dari data atau anggota observasi yang akan diteliti. Tabel 3 merupakan hasil dari uji heteroskedastisitas dengan menggunakan Eviews 10. Uji heteroskedastisitas ini menggunakan metode Breush-Pagan-Godfrey (BPG) dikarenakan jumlah observasi yang digunakan penulis cukup banyak, sehingga metode $B P G$ dianggap lebih layak untuk digunakan.

Hasil uji dapat dilihat dari nilai probabilitas chi square yang dibandingkan dengan nilai alpha $(\alpha)$ sebesar 5\% $(0,05)$. Berdasarkan Tabel 3 tersebut, diketahui bahwa nilai probabilitas chi-square adalah 0,159. Nilai tersebut lebih besar dibandingkan dengan nilai alpha $0,05(0,1591>0,05)$. Dengan demikian dapat dikatakan bahwa model regresi yang pertama (ROA) tidak terdapat masalah heteroskedastisitas. Begitupun dengan hasil uji heteroskedastisitas pada model regresi yang kedua $(N P F)$, nilai probabilitas chi-square $(0,4064)$ lebih besar dibandingkan dengan dengan nilai alpha 5\% (0,05). Dengan demikian dapat dikatakan bahwa model regresi kedua $(N P F)$ tidak terdapat masalah heteroskedastisitas.

Tabel 3. Hasil Uji Heteroskedastisitas

Heteroskedasticity Test: Breusch-Pagan-Godfrey (ROA)

\begin{tabular}{|c|c|c|}
\hline$\overline{F-s t a t i s t i c}$ & 1,475809 Prob. $F(14,57)$ & 0,1503 \\
\hline Obs $* R$-squared & 19,15516 Prob. Chi-Square (14) & $0,1591^{*}$ \\
\hline Scaled explained SS & 7,646980 Prob. Chi-Square (14) & 0,9069 \\
\hline \multicolumn{3}{|c|}{ Heteroskedasticity Test: Breusch-Pagan-Godfrey (NPF) } \\
\hline F-statistic & 1,035136 Prob. $F(14,57)$ & 0,4337 \\
\hline Obs*R-squared & 14,59490 Prob. Chi-Square (14) & $0,4064 *$ \\
\hline Scaled explained SS & 13,85006 Prob. Chi-Square (14) & 0,4609 \\
\hline
\end{tabular}

\section{Uji Autokorelasi}

Uji asumsi klasik yang terakhir adalah autokorelasi. Tabel 4 menunjukkan hasil uji autokorelasi dengan menggunakan metode Breusch-Godfrey (BG). Nilai probabilitas chi-square menunjukkan bahwa data observasi yang digunakan dalam penelitian terjadi autokorelasi, sehingga perlu dilakukan penyembuhan karena model dianggap tidak BLUE. Dikarenakan model terjadi autokorelasi, maka perlu dilakukan penyembuhan. Penyembuhan autokorelasi dilakukan dengan menggunakan metode Newey, Whitney and Kenneth atau yang biasa disebut dengan HAC (Heteroskedasticity and Autocorrelation Consistent Cocriance Matrix).

Tabel 4. Hasil Uji Autokorelasi

Breusch-Godfrey Serial Correlation LM Test (ROA):

\begin{tabular}{lrr}
\hline F-statistic & 8,699457 Prob. $F(2,55)$ & 0,0005 \\
Obs $*$-squared & 17,30305 Prob. Chi-Square (2) & 0,0002 \\
\hline \multicolumn{3}{c}{ Breusch-Godfrey Serial Correlation LM Test $(N P F):$} \\
\hline F-statistic & 8,790723 Prob. $F(2,55)$ & 0,0005 \\
Obs $* R$-squared & 17,44060 Prob. Chi-Square (2) & 0,0002 \\
\hline \multicolumn{2}{l}{ Sumber: data sekunder (diolah) }
\end{tabular}


Nilai Durbin Watson dapat diuji dengan menggunakan beberapa kriteria sebagai berikut: (a) $0<\mathrm{d}<\mathrm{dL}$ : ada autokorelasi positif; (b) $\mathrm{dL}<\mathrm{d}<\mathrm{dU}$ : daerah keragu-raguan, tidak ada keputusan; (c) $\mathrm{dU}<\mathrm{d}<4-\mathrm{dU}$ : tidak ada autokorelasi positif/negatif; (d) 4-dU<d<4-dL: daerah keragu-raguan; tidak ada keputusan; (e) 4-dL<d $<4$ : ada autokorelasi negatif.

Tabel 5. Hasil Uji Durbin Watson

\begin{tabular}{lccc}
\hline & Nilai d $_{\text {hitung }}$ & Kriteria & Metode \\
\hline Hasil Uji DW & 2,0166 & $\mathrm{dU}<\mathrm{d}<4-\mathrm{dU}$ & \multirow{2}{*}{$H A C$} \\
$\boldsymbol{R} \boldsymbol{O A}$ & & $1,87353<2,0166<2,07634$ & \\
Hasil Uji DW & 2,0186 & $\mathrm{dU}<\mathrm{d}<4-\mathrm{dU}$ & \multirow{2}{*}{$H A C$} \\
$\boldsymbol{N P F}$ & $1,87353<2,0186<2,07634$ & \\
\hline Sumb
\end{tabular}

Sumber: data sekunder (diolah)

Berdasarkan Tabel 5, dapat dijelaskan bahwa hasil uji Durbin Watson pada model regresi pertama $(R O A)$ adalah tidak terjadi autokorelasi. Hasil tersebut didasarkan pada nilai $d_{\text {hitung }}$ yang sesuai dengan kriteria uji, yaitu dU lebih kecil dibanding $\mathrm{d}_{\text {hitung }}$ dan $\mathrm{d}_{\text {hitung }}$ lebih kecil daripada 4-dU. Hasil yang sama juga terjadi pada model regresi yang kedua $(N P F)$, yaitu berdasarkan uji Durbin Watson, model yang digunakan tidak terjadi autokorelasi.

\section{Hasil Estimasi Regresi}

Tabel 6. Hasil Estimasi Regresi Model $1(R O A)$

\begin{tabular}{|c|c|c|c|c|}
\hline Variable & Coefficient & Std. Error & t-Statistic & Prob. \\
\hline $\mathrm{C}$ & $-0,130580$ & 0,086031 & $-1,517823$ & 0,1346 \\
\hline $\mathrm{X} 1$ & $-3,59 E-06$ & $5,07 \mathrm{E}-06$ & $-0,707843$ & 0,4819 \\
\hline $\mathrm{X} 2$ & $3,72 \mathrm{E}-05$ & 3,59E-05 & 1,037167 & 0,3040 \\
\hline X3 & 7,63E-07 & 7,00E-06 & 0,108971 & 0,9136 \\
\hline $\mathrm{X} 4$ & $9,43 \mathrm{E}-06$ & 4,58E-06 & 2,056529 & $0,0443 *$ \\
\hline X5 & $1,53 \mathrm{E}-06$ & $1,53 \mathrm{E}-06$ & 0,999274 & 0,3219 \\
\hline X6 & $-1,78 E-06$ & $1,62 \mathrm{E}-06$ & $-1,098757$ & 0,2765 \\
\hline $\mathrm{X} 7$ & $-7,95 \mathrm{E}-07$ & 3,47E-06 & $-0,229223$ & 0,8195 \\
\hline $\mathrm{X} 8$ & $-1,52 \mathrm{E}-05$ & $1,62 \mathrm{E}-05$ & $-0,935812$ & 0,3533 \\
\hline X9 & $1,46 \mathrm{E}-08$ & 4,37E-06 & 0,003336 & 0,9973 \\
\hline $\mathrm{X} 10$ & $1,24 \mathrm{E}-07$ & 2,81E-06 & 0,044184 & 0,9649 \\
\hline X11 & $6,84 \mathrm{E}-06$ & 8,37E-06 & 0,817431 & 0,4171 \\
\hline $\mathrm{X} 12$ & $-2,81 \mathrm{E}-05$ & $2,58 \mathrm{E}-05$ & $-1,087948$ & 0,2812 \\
\hline X13 & $1,57 \mathrm{E}-05$ & $1,28 \mathrm{E}-05$ & 1,224884 & 0,2257 \\
\hline $\mathrm{X} 14$ & $3,05 \mathrm{E}-06$ & $5,90 \mathrm{E}-06$ & 0,517169 & 0,6070 \\
\hline$R$-squared & 0,266044 & \multicolumn{2}{|c|}{ Mean dependent var } & 0,016875 \\
\hline Adjusted $R$-squared & 0,085774 & \multicolumn{2}{|c|}{ S.D. dependent var } & 0,019180 \\
\hline S.E. of regression & 0,018339 & \multicolumn{2}{|c|}{ Akaike info criterion } & $-4,976534$ \\
\hline Sum squared resid & 0,019170 & \multicolumn{2}{|c|}{ Schwarz criterion } & $-4,502229$ \\
\hline Log likelihood & 194,1552 & \multicolumn{2}{|c|}{ Hannan-Quinn criter. } & $-4,787712$ \\
\hline$F$-statistic & 1,475809 & \multirow{2}{*}{\multicolumn{2}{|c|}{ Durbin-Watson stat }} & 2,016616 \\
\hline Prob. (F-statistic) & $0,150252^{*}$ & & & \\
\hline
\end{tabular}

Sumber: data sekunder (diolah) 
Tabel 6 merupakan hasil estimasi regresi dengan variabel dependen $R O A$. Hasil estimasi ini menguji pengaruh diversifikasi pembiayaan berdasarkan sektor ekonomi terhadap profitabilitas yang digambarkan dengan ROA. Berdasarkan Tabel 6, terdapat 1 variabel independen yang secara parsial mempengaruhi profitabilitas perbankan syariah, yaitu X4 (industri pengolahan). Namun, secara simultan variabel independen tidak mempengaruhi profitabilitas perbankan syariah. Hal tersebut dapat dilihat pada nilai probabilitas uji $\mathrm{F}$ (F statistik) yang lebih besar daripada nilai alpha 5\% (0,05). Oleh sebab itu diversifikasi pembiayaan berdasarkan sektor ekonomi tidak berpengaruh terhadap profitabilitas (ROA) di perbankan syariah $\left(\mathrm{H}_{1}\right.$ ditolak).

Pada Tabel 7, hasilnya cukup berbeda jika dibandingkan dengan model regresi yang pertama. Pada model regresi kedua, terdapat beberapa variabel independen yang mempengaruhi secara parsial risiko gagal bayar di perbankan syariah, yaitu X6 (konstruksi), X11 (real estate, usaha persewaan dan jasa perusahaan) dan X13 (jasa kesehatan dan kegiatan sosial). Secara simultan, variabel independen memiliki pengaruh terhadap variabel dependen $(N P F)$ di perbankan syariah. Hasil tersebut dapat dilihat dari nilai probabilitas uji $\mathrm{F}$ ( $\mathrm{F}$ statistik) yang lebih kecil dibandingkan nilai alpha 5\% $(0,05)$. Oleh sebab itu diversifikasi pembiayaan berdasarkan sektor ekonomi berpengaruh terhadap risiko gagal bayar $(N P F)$ di perbankan syariah $\left(\mathrm{H}_{2}\right.$ diterima $)$.

Tabel 7. Hasil Estimasi Regresi Model 2 (NPF)

\begin{tabular}{|c|c|c|c|c|}
\hline Variable & Coefficient & Std. Error & t-Statistic & Prob. \\
\hline $\mathrm{C}$ & 6,905481 & 1,260535 & 5,478214 & 0,0000 \\
\hline $\mathrm{X} 1$ & 2,93E-05 & $6,12 \mathrm{E}-05$ & 0,478594 & 0,6341 \\
\hline $\mathrm{X} 2$ & 0,000598 & 0,000442 & 1,353661 & 0,1812 \\
\hline $\mathrm{X} 3$ & $-3,55 \mathrm{E}-05$ & $8,75 \mathrm{E}-05$ & $-0,406294$ & 0,6860 \\
\hline $\mathrm{X} 4$ & $-7,08 \mathrm{E}-05$ & $5,12 \mathrm{E}-05$ & $-1,383518$ & 0,1719 \\
\hline $\mathrm{X} 5$ & $-3,33 E-05$ & $2,11 \mathrm{E}-05$ & $-1,577580$ & 0,1202 \\
\hline X6 & $-5,08 \mathrm{E}-05$ & $1,88 \mathrm{E}-05$ & $-2,703101$ & $0,0090^{*}$ \\
\hline X7 & $4,13 \mathrm{E}-05$ & $3,52 \mathrm{E}-05$ & 1,174466 & 0,2451 \\
\hline $\mathrm{X} 8$ & $-0,000176$ & 0,000160 & $-1,094086$ & 0,2785 \\
\hline X9 & $-8,51 E-05$ & $5,77 \mathrm{E}-05$ & $-1,473612$ & 0,1461 \\
\hline $\mathrm{X} 10$ & $-1,35 E-05$ & 3,57E-05 & $-0,379165$ & 0,7060 \\
\hline $\mathrm{X} 11$ & $-0,000113$ & $6,16 \mathrm{E}-05$ & $-1,840887$ & $0,0708^{*}$ \\
\hline $\mathrm{X} 12$ & $-2,41 E-05$ & 0,000232 & $-0,103916$ & 0,9176 \\
\hline $\mathrm{X} 13$ & 0,000202 & $9,69 \mathrm{E}-05$ & 2,082555 & $0,0418 *$ \\
\hline $\mathrm{X} 14$ & $-1,34 \mathrm{E}-05$ & 7,34E-05 & $-0,182660$ & 0,8557 \\
\hline$R$-squared & 0,912100 & \multicolumn{2}{|c|}{ Mean dependent var } & 3,693193 \\
\hline Adjusted R-squared & 0,890510 & \multicolumn{2}{|c|}{ S.D. dependent var } & 0,572335 \\
\hline S.E. of regression & 0,189381 & \multicolumn{2}{|c|}{ Akaike info criterion } & $-0,307059$ \\
\hline Sum squared resid & 2,044317 & \multicolumn{2}{|c|}{ Schwarz criterion } & 0,167247 \\
\hline Log likelihood & 26,05411 & \multirow{2}{*}{\multicolumn{2}{|c|}{$\begin{array}{l}\text { Hannan-Quinn criter. } \\
\text { Durbin-Watson stat }\end{array}$}} & $-0,118236$ \\
\hline$F$-statistic & 42,24741 & & & 2,018553 \\
\hline Prob. (F-statistic) & $0,000000 *$ & & \\
\hline
\end{tabular}

Sumber: data sekunder (diolah) 


\section{Diversifikasi Pembiayaan Sektor Ekonomi Dan Profitabilitas}

Berdasarkan hasil uji regresi yang sudah disampaikan sebelumnya bahwa $\mathrm{H}_{1}$ ditolak, artinya diversifikasi pembiayaan berdasarkan sektor ekonomi secara signifikan tidak mempengaruhi profitabilitas perbankan syariah di Indonesia. Hasil tersebut berbeda dengan hasil penelitian Masruroh (2018b) yang menyatakan bahwa diversifikasi pembiayaan berdasarkan sektor ekonomi berpengaruh negatif terhadap profitabilitas perbankan syariah. Selain itu, penelitian lainnya yang tidak sejalan adalah penelitian yang dilakukan oleh Prastiwi and Anik (2020) yang menyatakan bahwa diversifikasi kredit berdasarkan sektor ekonomi mempengaruhi kinerja perbankan, terutama pada profitabilitas. Hal itu didasarkan pada nilai HHI (Herfindahl-Hirschman Index) sebesar 0,21 yang berarti bahwa semakin mendekati nilai 0 diversifikasi cenderung tinggi. Walaupun diversifikasi cenderung tinggi, akan tetapi profitabilitas perbankan tetap tumbuh.

Hasil penelitian terdahulu yang tidak sejalan dengan hasil penelitian ini, disebabkan terdapatnya nilai $N P F$ yang masih lebih tinggi dibandingkan profitabilitas (ROA). Oleh sebab itu, perbankan syariah harusnya bisa menggenjot profitabilitas dengan mengembangkan atau melakukan ekspansi bisnis yang lebih profitable. Selain itu, efisiensi atas biaya-biaya yang harus ditanggung oleh perbankan syariah juga harus ditingkatkan, karena akan berdampak pada peningkatan pertumbuhan bank syariah (Syafrida and Aminah 2015). Ningsih, Badina, and Rosiana (2016) dalam penelitiannya menyatakan bahwa rasio BOPO berpengaruh negatif terhadap profitabilitas (ROA). Maknanya adalah semakin tinggi tingkat rasio BOPO yang diperoleh, maka ROA akan menurun (Gambar 2).

Gambar 2. ROA Perbankan Syariah Indonesia

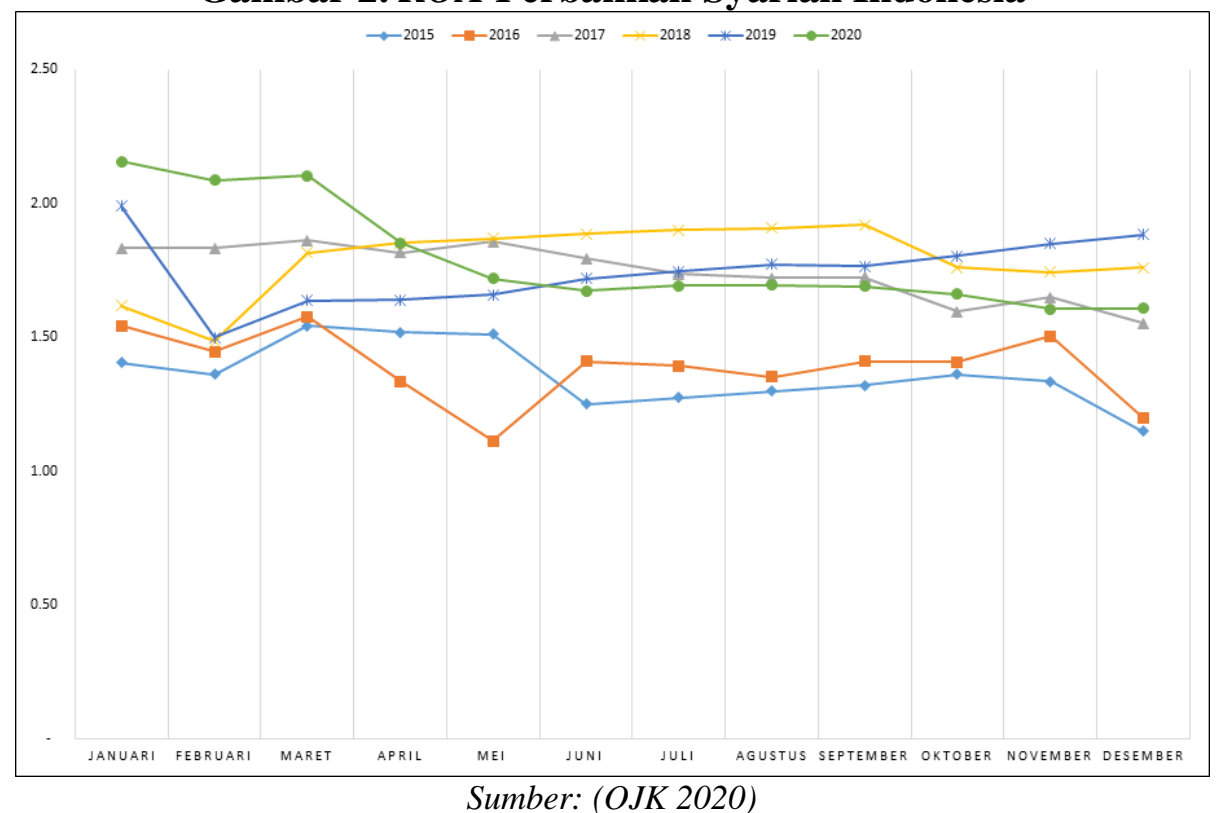

Ekspansi bisnis dengan cara digitalisasi transaksi pada bisnis perbankan syariah belakangan ini dapat menjadi salah satu cara atau upaya dalam melakukan efisiensi. Digitalisasi pada perbankan syariah merupakan suatu langkah inovatif agar dapat menarik masyarakat untuk menggunakan produk bank syariah. 
Berdasarkan data OJK (2017) masyarakat sudah mulai cukup banyak yang beralih dari transaksi konvensional menjadi transaksi digital berbasis $e$-channel perbankan. Selain itu, dengan adanya digitalisasi pada produk perbankan syariah juga akan meningkatkan inklusi keuangan di Indonesia (Ahyar 2019). Meningkatnya inklusi keuangan menandakan bahwa semakin banyak masyarakat yang menggunakan produk dan jasa di perbankan syariah. Ketika banyak masyarakat yang menggunakan produk dan jasa perbankan syariah, maka kesempatan serta potensi perbankan syariah untuk meningkatkan bisnis yang profitable menjadi semakin besar.

\section{Diversifikasi Pembiayaan Sektor Ekonomi Dan Risiko}

Secara umum, risiko yang sudah pasti oleh perbankan tidak terkecuali perbankan syariah adalah risiko gagal bayar. Risiko gagal bayar pada perbankan syariah digambarkan dalam suatu rasio yang disebut dengan $N P F$. Berdasarkan hasil penelitian bahwa $\mathrm{H}_{2}$ diterima, artinya bahwa diversifikasi pembiayaan pada sektor ekonomi dapat menekan risiko gagal bayar $(N P F)$. Hasil penelitian ini sejalan dengan penelitian yang dilakukan oleh Prastiwi and Anik (2020); Christianti (2011), yang menyatakan bahwa diversifikasi pembiayaan pada sektor ekonomi berpengaruh positif dalam menurunkan tingkat risiko gagal bayar $(N P F)$. Sedangkan hasil penelitian ini bertolak belakang dengan hasil penelitian yang dilakukan oleh Belguith and Bellouma (2017); Mulwa (2018) yang menyatakan bahwa diversifikasi kredit berdasarkan sektor ekonomi pada perbankan dapat meningkatkan risiko kredit.

Hasil penelitian ini dapat menjawab teori Markowitz (1952) bahwa aset harus disebar ke dalam beberapa portofolio atau instrumen investasi. Menurut Lis et al. (2000), salah satu faktor yang yang mempengaruhi level atau tingkat kredit bermasalah adalah komposisi portofolio kredit. Komposisi kredit sendiri dapat diartikan diversifikasi kredit atau pembiayaan, baik berdasarkan sektor ekonomi, tujuan kredit, atau berdasarkan skema akad (syariah).

\section{Gambar 3. NPF Perbankan Syariah Indonesia}

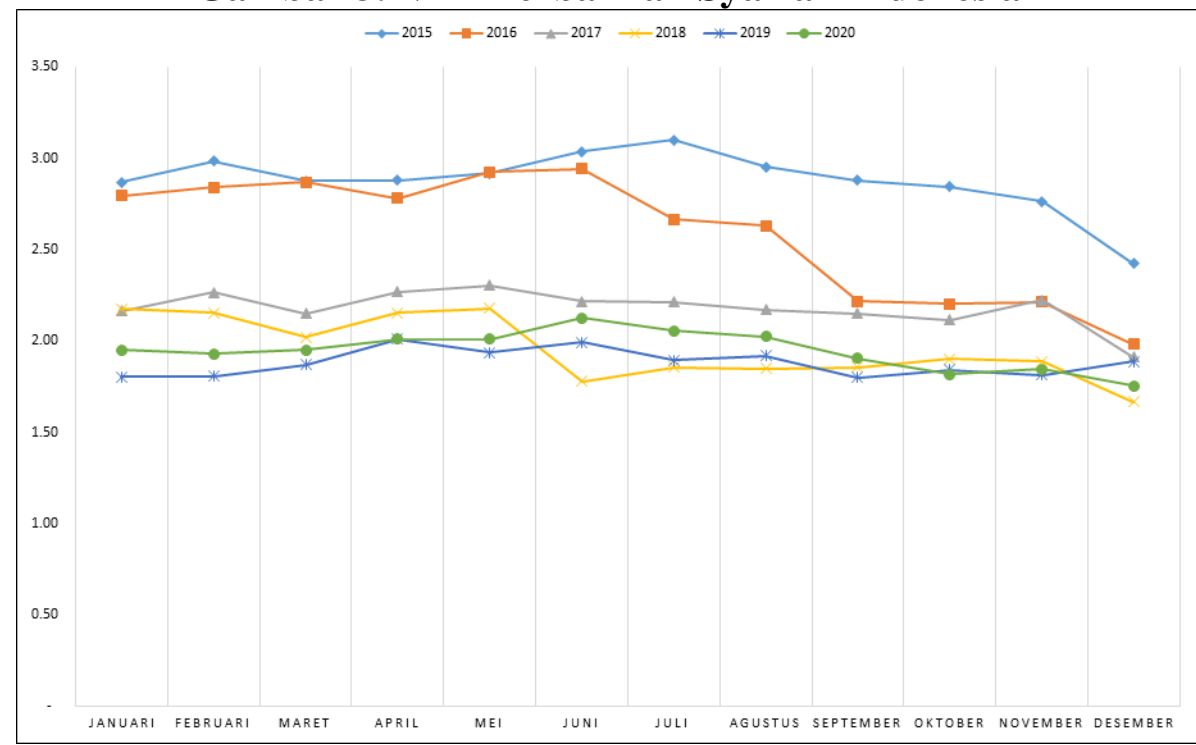

Sumber: (OJK 2020) 
Berdasarkan Gambar 3, NPF pada perbankan syariah Indonesia mengalami penurunan sejak tahun 2015. Namun, pada tahun 2020 terjadi sedikit peningkatan NPF dibandingkan tahun 2019. Hal tersebut disebabkan oleh Kejadian Luar Biasa Pandemi Covid-19 di Indonesia yang terjadi sejak Maret 2020. Walaupun begitu, $N P F$ bank syariah masih tetap terjaga di bawah angka $5 \%$ karena para otoritas seperti OJK, Bank Indonesia, Kementerian Keuangan dan Lembaga Penjamin Simpanan yang tergabung di dalam Komite Stabilitas Sistem Keuangan (KSSK) sepakat untuk melakukan restrukturisasi pada kredit dan atau pembiayaan. Sebagai salah satu indikator kinerja bank syariah, rasio NPF harus bisa dikelola dengan baik agar menghasilkan kinerja keuangan yang baik juga. Kinerja bank syariah yang baik akan menarik para masyarakat untuk menggunakan produk di bank syariah.

\section{KESIMPULAN}

Diversifikasi pembiayaan berdasarkan sektor ekonomi tidak mempengaruhi profitabilitas bank syariah di Indonesia. Asumsi peneliti hal tersebut terjadi karena rasio NPF yang masih lebih tinggi dibandingkan dengan rasio $R O A$. Selain itu, pemilihan secara selektif terhadap sektor yang lebih profitable masih kurang optimal. Kemudian diversifikasi pembiayaan berdasarkan sektor ekonomi mempengaruhi risiko gagal bayar di bank syariah. Diversifikasi pembiayaan pada sektor ekonomi dapat menekan rasio NPF sebagai gambaran risiko gagal bayar.

Hasil penelitian ini dapat berimplikasi pada menurunnya NPF pada bank syariah yang menandakan bahwa kinerja serta kualitas pembiayaan di bank syariah semakin membaik. Selain itu, bank syariah juga akan lebih berhati-hati dalam menyalurkan pembiayaan. Penelitian ini memiliki keterbatasan, yaitu masih minimnya penelitian ataupun teori yang membahas tentang diversifikasi pembiayaan pada sektor ekonomi di perbankan syariah.

Kepada perbankan syariah diharapkan untuk bisa lebih selektif dalam memilah dan memilih pembiayaan sektor ekonomi yang lebih profitable. Selain itu, diharapkan agar lebih efisien dalam menjalankan aktifitas atau kegiatan bisnis bank syariah supaya bisa menekan biaya-biaya atau pengeluaran yang tidak terlalu penting. Dengan demikian profitabilitas bank syariah dapat meningkat lebih baik sesuai yang diharapkan, sehingga bisa meningkatkan kinerja keuangan bank syariah. Kemudian risiko gagal bayar serta rasio $N P F$ dapat terkendali dengan baik. Kepada peneliti selanjutnya disarankan bisa menambah variabel risiko diluar risiko gagal bayar $(N P F)$ serta variabel profitabilitas lainnya.

\section{DAFTAR PUSTAKA}

Anshori, Abdul Ghofur. 2018. Perbankan Syariah di Indonesia. Yogyakarta: Gadjah Mada University Press.

Ahyar, Muhammad Khozin. 2019. "Fintech Dan Perbankan Syariah.” Kedaulatan Rakyat, September 2019.

Belguith, Houda, and Meryem Bellouma. 2017. "The Impact of Loan Portfolio Diversification on Tunisian Bank's Profitability." International Journal of 
Emerging Research in Management \& Technology, 6 (6): 35-45. https://doi.org/10.23956/ijermt.v6i6.242.

Christianti, Ari. 2011. "Diversifikasi Kredit Terhadap Profitabilitas Dan Probabilitas Kegagalan Bank." Jurnal Keuangan dan Perbankan (JKP), 15 (3): 428-436. https://jurnal.unmer.ac.id/index.php/jkdp/article/view/1035.

Karim, Adiwarman A. 2014. Bank Islam: Analisis Fiqih Dan Keuangan. Edisi Keem. Jakarta: Rajawali Pers.

Lis, Santiago Fernández De, Jorge Martínez Pagés, and Jesús Saurina. 2000.

"Credit Growth, Problem Loans and Credit Risk Provisioning in Spain."

Documentos de Trabajo Del Banco de España, 18: 1-32. https://repositorio.bde.es/bitstream/123456789/6709/1/dt0018e.pdf.

Mansur, Ahmad. 2011. "Peran Bank Syariah Di Dalam Pembangunan Ekonomi: Analisis Teoritis Atas Mobilisasi, Alokasi dan Utilisasi Sumber Daya Ekonomi". el-Qist: Journal of Islamic Economics and Business (JIEB), 1 (1): 63-88. http://jurnalfebi.uinsby.ac.id/index.php/elqist/article/view/44.

Mahmudah, Rizka Rosdiana. 2017. "Pengaruh Profitabilitas, Ukuran Perusahaan (Size) Dan Equivalent Rate Terhadap Dana Pihak Ketiga Pada Bank Syariah Di Indonesia Periode 2012-2016.” Skripsi IAIN Surakarta.

Markowitz, Harry. 1952. "Portfolio Selection". The Journal of Finance, 7 (1): 77 91.

Masruroh, Maulida. 2018a. "Diversifikasi Pembiayaan Sebagai Strategi Manajemen Risiko Kredit Dan Risiko Likuiditas Pada Bank Syariah Di Indonesia." Thesis Univeristas Islam Negeri Sunan Kalijaga Yogyakarta. https://digilib.uin-suka.ac.id/id/eprint/35409/.

—. 2018b. "Diversifikasi Pembiayaan Sebagai Upaya Peningkatan Profitabilitas Di Bank Syariah." Al-Tijary: Jurnal Ekonomi dan Bisnis Islam, 3 (2): 117- 130. https://doi.org/10.21093/at.v3i2.1102.

Muhamad. 2015. Manajemen Dana Bank Syariah. Jakarta: Rajawali Pers.

Mulwa, Jonathan Mwau. 2018. "Sectoral Credit Diversification, Bank Performance and Monitoring Effectiveness; a Cross-Country Analysis of East African Banking Industries." Journal of Finance Investments Analysis 7

$17-36$.

https://econpapers.repec.org/article/sptfininv/v_3a7_3ay_3a2018_3ai_3a2 _3af_3a7_5f2_5f2.htm.

Ningsih, Widiya, Tenny Badina, and Rita Rosiana. 2016. "Determinan Profitabilitas Bank Pembiayaan Rakyat Syariah Di Indonesia." Akuntabilitas: Jurnal Ilmu Akuntansi, 9 (2): 207-214. http://journal.uinjkt.ac.id/index.php/akuntabilitas/article/view/4024.

Nuryanto, and Zulfikar Bagus Pambuko. 2018. Eviews Untuk Analisis Ekonometrika Dasar: Aplikasi Dan Interpretasi. Magelang: Unimma Press.

OJK. 2017. Strategi Nasional Literasi Keuangan Indonesia. Jakarta: Otoritas Jasa Keuangan Republik Indonesia. https://www.ojk.go.id/id/berita-dankegiatan/publikasi/Documents/Pages/Strategi-Nasional-Literasi-

Keuangan-Indonesia-(Revisit-2017)-/SNLKI\%20(Revisit\%202017).pdf.

OJK. 2018. Batas Maksimum Pemberian Kredit Dan Penyediaan Dana Besar Bagi Bank Umum. Jakarta: Otoritas Jasa Keuangan Republik Indonesia. https://www.ojk.go.id/id/regulasi/Documents/Pages/Batas-Maksimum- 
Pemberian-Kredit-dan-Penyediaan-Dana-Besar-Bagi-Bank-

Umum/pojk\%2032-2018.pdf.

OJK. 2020. Statistik Perbankan Syariah 2015-2020. Jakarta: Otoritas Jasa Keuangan RI. https://www.ojk.go.id/id/kanal/syariah/data-danstatistik/statistik-perbankan-syariah/default.aspx.

OJK. 2021. Perbankan Syariah dan Kelembagaannya. Jakarta: Otoritas Jasa Keuangan RI. https://www.ojk.go.id/id/kanal/syariah/tentangsyariah/Pages/PBS-dan-Kelembagaan.aspx.

Prastiwi, Iin Emy, and Anik Anik. 2020. "Diversifikasi Kredit, Monitoring, Dan Kinerja Perbankan Di Indonesia." Jurnal Ilmiah Ekonomi Islam (JIEI), 6 (1): 80-86. https://doi.org/10.29040/jiei.v6i1.775.

Presiden RI. 2008. Undang-Undang Nomor 21 Tahun 2008 Tentang Perbankan Syariah. Jakarta: Presiden Republik Indonesia. https://www.ojk.go.id/waspada-

investasi/id/regulasi/Documents/UU_No_21_Tahun_2008_Perbankan_Sya riah.pdf

Puspitasari, Novi. 2018. Keuangan Islam Teori Dan Praktik. Yogyakarta: UII Press.

Saufanny, Annisa Difa, and Siti Khomsatun. 2019. "Corporate Governance Dan Pengungkapan Manajemen Risiko Bank Syariah Di Indonesia." JAKIS: Jurnal Akuntansi Dan Keuangan Islam, 5 (1): 47-61. https://doi.org/10.35836/jakis.v5i1.13.

Suryanto, Asep, and Agus Ahmad Nasrulloh. 2016. "Pengaruh Diversifikasi Produk Pembiayaan Terhadap Profitabilitas Perbankan Syariah Di Indonesia." JES: Jurnal Ekonomi Syariah 1 (1): 1-13. http://jurnal.unsil.ac.id/index.php/jes/article/view/902.

Syafrida, Ida, and Indianik Aminah. 2015. "Faktor Perlambatan Pertumbuhan Bank Syariah Di Indonesia Dan Upaya Penanganannya." Jurnal Ekonomi dan Bisnis, $\quad 14 \quad$ (1): https://jurnal.pnj.ac.id/index.php/ekbis/article/view/753.

Wahyudi, Imam, Miranti Kartika Dewi, Fenny Rosmanita, Muhammad Budi Prasetyo, Niken Iwani Surya P. 2013. Manajemen Risiko Bank Islam. Jakarta: Salemba Empat - Muamalat Institute.

Widarjono, Agus. 2018. Ekonometrika Pengantar Dan Aplikasinya Disertai Panduan EViews. Kelima. Yogyakarta: UPP STIM YKPN. 